\title{
The Effects of Station Rotation Model (SRM) and Lecture Method on Blended learning on Secondary School Students' Performance on Reading Comprehension
}

\author{
B. A. Ogude ${ }^{1 *}$, C. O. Chukweggu ${ }^{2}$
}

${ }^{1}$ Department of Curriculum Studies and Educational Technology, University of Port Harcourt, University of PMB 5323 Choba, East-West Rd, Port Harcourt, Nigeria

${ }^{2}$ Professor, Department of Curriculum Studies and Educational Technology, University of Port Harcourt, University of PMB 5323 Choba, East-West Rd, Port Harcourt, Nigeria

\author{
DOI: $10.36348 / J A E P .2019 . v 03 i 10.006$ \\ | Received: 07.10.2019 | Accepted: 14.10.2019 | Published: 30.10.2019
}

*Corresponding author: B. A. Ogude

\section{Abstract}

The study investigated the effects of Station Rotation Model (SRM) in public secondary school students' performance in reading comprehension in Delta State, using a quasi- experimental design of the pretest, protest and control type. A sample of 50 students were randomly selected using a purposive sampling technique on a population of 1480 students of SSS II in three schools in three Local Government Areas of Delta State. The instrument to elicit students' Performance is Reading Comprehension Performance Test (RCPT) pretest and posttest with reliability coefficients of 0.78 and 0.84 respectively. Three research questions were formulated to guide the study while three hypotheses were stated and tested at 0.05 significance level. Data collected were analyzed using the descriptive statistics of mean and percentage to answer research questions while inferential statistics of analysis of covariance (ANCOVA) was used to test hypotheses. Results show that at 0.05 significance level and $\mathrm{df}(2,99)$ there is no significant difference between students mean performance taught Reading comprehension using the Station Rotation Model and those taught using the Lecture Method. There is no significant difference between the mean performance scores of the male and female students taught reading comprehension using the Station Rotation Model (SRM) form of blended learning strategy. However, descriptive analysis show that the mean difference performance scores of the female students is greater than those of their male counterparts $(6.52>5.44)$.

Keywords: Station Rotation Model (SRM), pretest and posttest, Reading Comprehension Performance Test (RCPT).

Copyright @ 2019: This is an open-access article distributed under the terms of the Creative Commons Attribution license which permits unrestricted use, distribution, and reproduction in any medium for non-commercial use (NonCommercial, or CC-BY-NC) provided the original author and sources are credited.

\section{INTRODUCTION}

Reading has shown to be a complex intellectual process that involves decoding symbols to construct and derive meaning [1]. Reading is means for acquiring language, communication, and for information and idea sharing. It is complex interaction between text and their reader which is shaped by prior knowledge, attitude, experiences and language community of reader in which they are socially and culturally situated. Reading process needs continual practice, enhancement, refinementa, creativity and nalysis.

Reading comprehension is the construction of meaning from printed material. It is interactive process that requires the use of background knowledge, which the reader brings, in combination with the material that is found on the printed page. Readers connect what they already know with information in the text [2]. Reading comprehension depends on many factors: the student's knowledge and experiences, word recognition strategies, thinking abilities, perpetual and sensory abilities, as well as their purpose for reading and familiarity with various comprehension (learning) strategies. There are also text-based factors to consider, including gender, quality of the text, and the difficulty of the concepts being taught [3]. It does not consist of a single ability as most people think. It includes: recognizing individual words, group words into thought units and relating the thought units into a meaningful sentence, paragraph, chapter or book.

Traditional reading approach has exposed students to two main difficulties in reading that is they don't fully develop phonemic awareness and do not know how to decode the meaning of vocabularies hence 
reading of letters, words and sentences become difficult. The teacher, therefore teaches whole words, sight sounds, phrases and segmented parts of sentences as well as the relationship between graphemes and phonemes in phonics instruction. Reading is achieved through the effective application of the two traditions of whole word instruction and phonics instruction.

The extensive contemporary use of technology in education ICT in schools as innovative teaching strategy for concept delivery was mainly to educate students and generate knowledge for advancement of national development. In teaching, it ensures the improvement of quality of teaching, learner centeredness and ameliorates difficulties in effective learning encountered by learners. Olele and Nwabueze [4] stated that two important advances over the last twenty-five years call for change in methods, techniques and teaching in the classroom is to remedy through proper understanding of how people learn (where students engage in learning activities actively) and their active engagement in information retrieval especially in the digital era. ICT-based instructional strategies scaffold students learning, enabling them construct meaning, knowledgeable, and collaborate with others using visual and audio materials [5]. This has in recent times transformed the traditional classroom and teaching methods to exciting innovations that has made learning rewarding.

Instructional technique inspires or motivate students to concentrate, organize information for proper comprehension and remembering, control and assess their learning. To turn out as successful technical learners, students require stages of strategic instruction, various instructional methods and detailed rich learning materials; suitable support which includes guided practice, modelling and independent practice; chances to transfer knowledge and skills; expressive connections between idea and skills and real-life circumstances, opportunities to become independent and display what they have in terms of knowledge; encourage personal monitor and personal correct, tools to reflect on and assess their learning. Effective instruction-based and learning technique are used across grade levels and subject areas and can accommodate range of learner's differences.

Blended learning has been purposed as an effective strategy for teaching reading comprehension. Kheirzadeh and Birgani [6] reported the effectiveness of Blended learning in improving reading comprehension among Iranian EFL students. The process involved a combination of online Digital media and the conventional face to face teaching methods (blended). Although the blended learning strategy can significantly decrease the cost of education, it has encouraging increase in educational attainment and efficiency among students. AL Filky [7] described blended learning as consisting of the following features, it is a student centred learning process, it involved student-teacher, student-student, and student content, and student-outside resources communication. It is technology-based, modern and effective. Blended learning widens the spaces and chances accessible for learning, affording influence of technology on reading comprehension which can enable reading achievement among youths categorized by limited literacy skills [8].

The combination of online and face to face instruction. The use of the blended learning approach is mainly due to the following advantages:

- It enables students take responsibility for their learning process.

- It involves online learning taking cognizance of student's personalization. Students can learn at their own pace.

- The learning process is convenient and flexibility where learners can integrate efforts to effective learning outside the classroom.

- It affords parents/guardian to participate meaningfully in their children's education.

- Teachers become advantaged in teaching their students irrespective of their cognitive styles.

The typology of the Blended learning strategies are: the Rotation Model, Flex Model, Enhanced Virtual Model and A la Carte model. The rotation model subdivided into the station rotation, lab rotation; Flipped classroom and individual Rotation [9]. The choice of the Station Rotation Model is that it offers a constructivism and collaborative approach to learning.

The Station Rotation Model (SRM) form of blending learning, is advantageous in teaching reading comprehension for the following reasons:

It rotates between different types of classrooms-online offline, classes with a teacher and involved collaborative activities. Rotation could be from online to and paper assignments. Students take advantages of technology to learn reading language by total language immersion. It triumphs in education because it allows teachers monitor their students performance as a group or as an individual hence allowing for effective students evaluation on. The advantage of teacher guided instruction and collaborative learning among learners evidenced in the use of rotation model of the type station rotation model (STM) include teacher active univoration to application of technology in learning especially reading compression, of development of effective communication skills and content delivery in experiencing the wholeness of classroom processes and experiences, while the learners become active, meaningful learners, co-operation, engaged learning and enhanced performance. 
Figure-1 below captures critical elements such as Reading, Types of Reading, reading comprehension, performance and the competitive Learning strategies of Station Rotation Model (SRM) of Blended Learning strategy and the effect of this teaching strategy and gender on performance of students in reading comprehension.

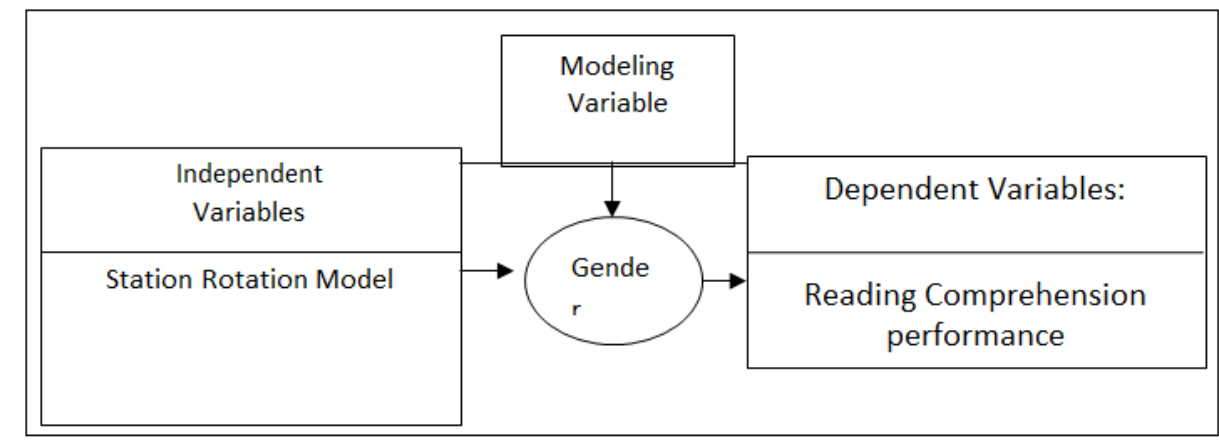

Fig-1: Schematic Representation of independent, dependent and modeling variables of the study

The station rotation model and effect on reading, performance and its influence on gender is mainly discussed in this work. Reading is the interaction between the writer and the reader. It has to do with the retrieval of information which are written down. It is not necessarily a process observable and carried out in schools but is a basic skill individuals engage in, throughout life. Reading is an aspect of leaning and indispensable in sustaining the development of any society $[10,11]$.
Blended Learning strategy in corporate different models as shown in Fig-2. it is part of the wide selection of educational technological innovation that transform the education process and improve students acquisition of meaningful Knowledge. The use of the blended instruction is critical because it decides the entire approach to the instruction in terms of design and pedagogy of instruction.

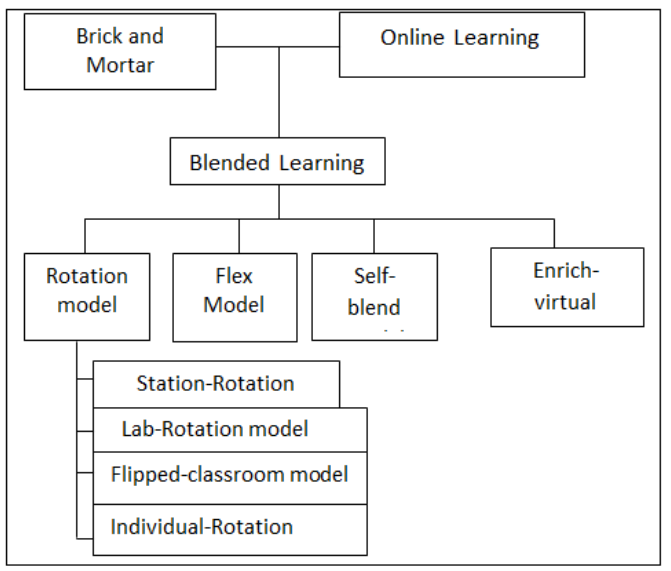

Fig-2: Adopted Blended-learning taxonomy [12]

According to Kim [13], the blended learning is formal education programs in which a student learns in part via online delivering of instruction with some student control of time and space and is part undergo supervision in Brickyard mortar location away from home.

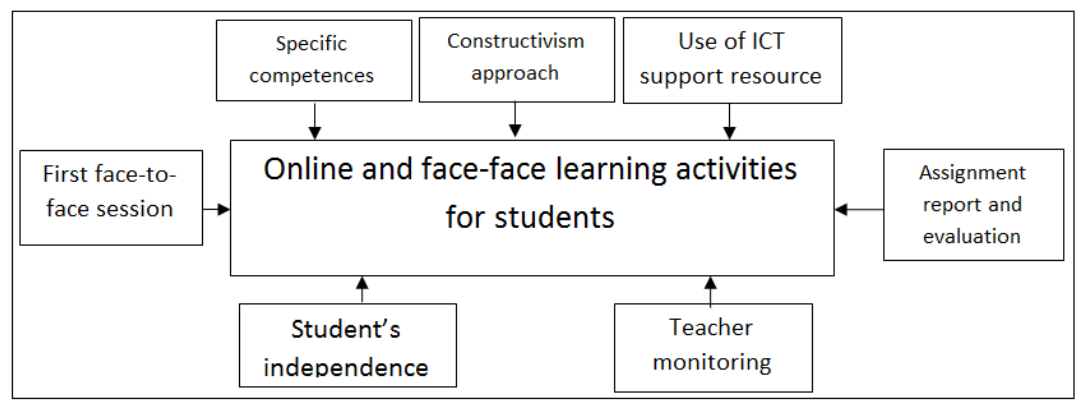

Fig-3: Station Rotation Model [1] 
Figure-3 depicts the categorization scheme for blended learning. Insight on the Figure reveals two components of the same process. The online learning which is otherwise called the virtual learning of or cyber learning and e-learning emphasizing technologyrich instruction in which learners' interface the computer and retrieve or read information built-in.

The second component is the 'supervised 'brick-and- mortar approach is which learning must take place away from home. The brick and mortar traditional instruction approach focuses on face to face teacher-centred instruction where teacher could head a discussion and impart to learners' new concepts, ideas instructional materials such as books, lectures or individual written assignments. In the technology-rich instruction, the mix of traditional instruction with digital enhancements is carried out. The use of digital texts, white boards document cameras and internet tools.

\section{Statement of the Problem}

The digital resources in education has afforded readers unimaginable opportunity to have access to the world around through diverse literatures and information networks averse in the internet integrity ICT into content delivery despite navigation and screen reading difficulties, students would have the motivation to use digital resources due to the excitements, word and pictorial representations and technology applications to remedy their performance reading.

\begin{tabular}{|c|c|c|c|c|c|c|c|c|c|}
\hline \multirow[t]{2}{*}{ YEAR } & \multirow[t]{2}{*}{$\begin{array}{c}\text { TOTAL } \\
\text { ENROLLED }\end{array}$} & \multirow[t]{2}{*}{$\begin{array}{c}\text { TOTAL } \\
\text { PRESENT }\end{array}$} & \multirow[t]{2}{*}{$\begin{array}{c}\text { TOTAL } \\
\text { ABSENT }\end{array}$} & \multicolumn{3}{|c|}{ Credit (1-6) } & \multicolumn{3}{|c|}{$\begin{array}{l}\text { PASS (7-8) } \\
\text { FAIL (F9) }\end{array}$} \\
\hline & & & & $\begin{array}{c}\text { No of } \\
\text { candidate }\end{array}$ & $\begin{array}{c}\% \\
\text { (credit) }\end{array}$ & $\begin{array}{c}\text { No. } \\
\text { of } \\
\text { candidate }\end{array}$ & $\begin{array}{c}\% \\
\text { (Passes) }\end{array}$ & $\begin{array}{c}\text { No of } \\
\text { candidate }\end{array}$ & $\begin{array}{c}\% \\
\text { (fail) }\end{array}$ \\
\hline 2001 & 1040101 & 1025027 & 15074 & 267251 & 25.69 & 316767 & 30.46 & 441009 & 42.40 \\
\hline 2002 & 925289 & 909888 & 15401 & 223568 & 24.16 & 299562 & 32.27 & 387758 & 41.91 \\
\hline 2003 & 939507 & 929271 & 10236 & 269824 & 28.72 & 320185 & 34.08 & 314225 & 33.45 \\
\hline 2004 & 844540 & 833204 & 11336 & 252271 & 29.87 & 257954 & 30.44 & 323879 & 38.35 \\
\hline 2005 & 1080162 & 1064587 & 15575 & 272922 & 25.27 & 371095 & 34.36 & 393201 & 36.40 \\
\hline 2006 & 1170523 & 1154266 & 16257 & 375007 & 32.04 & 393994 & 33.66 & 342311 & 29.24 \\
\hline 2007 & 1270137 & 1252570 & 17567 & 379831 & 29.90 & 466378 & 36.72 & 379006 & 29.84 \\
\hline 2008 & 1292910 & 12741566 & 18744 & 446285 & 34.52 & 405942 & 31.40 & 400126 & 30.95 \\
\hline 2009 & 1373009 & 1355725 & 17284 & 563294 & 41.03 & 400424 & 29.16 & 3149655 & 22.94 \\
\hline 2010 & 1331381 & 1307745 & 23636 & 459404 & 34.51 & 407722 & 30.62 & 405677 & 30.47 \\
\hline
\end{tabular}

There have been persistent students' poor performance has continued in a down turn over the years (as shown in Table-1). The consequences are the increase in cost of enrolment for external examinations among students (WASSCE \& NECO) and decrease in students' enrolment for higher education given the fact that, a credit pass in English language is one of the compulsory requirements for all courses in higher education in Nigeria (universities and polytechnics). When students do not improve in comprehension in English, literacy level pummel, even in other subjects where information is presented in English. The statement of the problem is whether the use of Station Rotation Model in teaching English language reading of comprehension would improve student performance in reading.

\section{Aim and Objectives of the Study \\ The aim of this research is to investigate impact of Station Rotation Model (SLM) of Blended Learning technique on secondary school students' performance in reading comprehension.}

Specifically, the objectives of the study are to:
1. Determine the difference in mean academic performance scores of students taught reading comprehension using the Station Rotation Model (SRM) of blended learning strategy and those taught using the Lecture Method (LM).

2. Evaluate the difference in Mean academic performance scores of students taught reading comprehension using the Station Rotation Model (SRM) of blended learning strategy and those taught using the Lecture Method (LM), given their gender.

\section{Hypotheses}

The following null-hypotheses were stated and tested at 0.05 significance level

$\mathbf{H}_{\mathbf{0 1}}$. There is no significant difference between mean academic performance scores of students' taught reading comprehension using Station Rotation Model (SRM) of Blended Learning Strategy and those taught with the Lecture Method (LM).

$\mathbf{H}_{\mathbf{0 2}}$. There is no significant difference between mean scores of Students taught reading comprehension using interactive reading model 
strategy and those taught with the Lecture Method (LM).

\section{METHODOLOGY}

In order to evaluate students performance in reading comprehension using the Station Rotation Model learning strategy, a quasi-experimental design of the pretest, post test control type is used on 100 students randomly selected using the purposive random technique and paper balloting randomization method. The instrument Reading Comprehension Performance Test (RCPT) consisting of 14 questions, Pretest (WAEC 1998) and post test (RCPT) validated by three experts in the university of Port Harcourt, dept. of English studies. RCPT and CPTV have reliability coefficients of 0.82 and 0.78 obtained using the test-retest method and Pearson Product Moment reliability formula (PPMC). The pretest (WAEC) was administered on the students' before teaching using instructional packages, lesson plans on Station Rotation Model (LPSRM) and Lesson Plan on Lecture Method (LPLM) on concept of domestic violence, corruption and gender and access to secondary education. The post test RCPT was administered. The maximum score of RCPT is 28 marks. Each item scores 2 marks. The responses of students on RCPT (pretest and post test) were collated and analyze using descriptive analyses of mean (Mean \%) and inferential analysis of Covariance (ANCOVA).

\section{Scope of the Study}

The study focused on the academic performance of SSS II students, the use of the instructional learning strategies: Station Rotation Model (SRM) of blended learning strategy and Interactive Reading Model (IRM) which are the independent variable were used to evaluate how it affects student's academic performance in reading comprehension. The moderating variable that is considered in this study is gender on academic performance of students in reading comprehension. The Station Rotation Model instructional strategy is selected for the study because little or no attention has been given it by researchers in the research area. The study was carried out among selected public secondary schools in three local government areas of Delta State. The class used for the study is the SSS II where the concepts of comprehension, summary and essay writing is emphasized according to the national curriculum on education for English language. The content areas of the comprehension passages are on domestic violence in Nigerian society, the menace of corruption in Nigeria, gender inequality and access to secondary school education.

\section{RESULTS}

\section{Research Question 1}

What is the difference between mean academic performance scores of students taught reading comprehension using the Station Rotation Model (SRM) of blended learning and the Lecture Method?

Table-1: Mean scores of students taught reading comprehension using Station Rotation Model and lecture method $\mathbf{N}=\mathbf{5 0}$

\begin{tabular}{|c|c|c|c|c|c|}
\hline $\mathbf{S} / \mathbf{N}$ & GROUP & $\begin{array}{l}\text { TEACHING } \\
\text { STRATEGY }\end{array}$ & $\begin{array}{l}\text { MEAN PRE- } \\
\text { TEST }\end{array}$ & $\begin{array}{l}\text { MEAN } \\
\text { POST- } \\
\text { TEST }\end{array}$ & $\begin{array}{l}\text { MEAN DIFFERENCE } \\
\bar{D}\end{array}$ \\
\hline $\begin{array}{ll}\text { i. } & \text { D } \\
\text { ii. } & \text { S } \\
\text { iii. } & \end{array}$ & $\begin{array}{l}\text { Experimental } \\
\text { Control }\end{array}$ & $\begin{array}{l}\text { SRM } \\
\text { IRM } \\
\text { LM }\end{array}$ & $\begin{array}{l}9.36 \\
11.82 \\
10.32\end{array}$ & $\begin{array}{l}15.26 \\
13.18 \\
11.06\end{array}$ & $\begin{array}{l}5.9 \\
0.16 \\
0.74\end{array}$ \\
\hline
\end{tabular}

\section{Station Rotation Model (SRM) \\ Interactive Reading Model (IRM) \\ Lecture Method (LM)}

The table shows that the mean performance score of those taught reading comprehension using the Station Model (SRM) form of blended learning model (BLM) and those taught using lecture method are 5.9 and 0.74 respectively. The mean pretest score of the students who learnt using SRM is 9.36 while the mean post-test score is $15.26(\bar{x}=15.26)$ while the mean pretest score of those who learnt reading comprehension using the lecture method is 10.32 and the mean post test score $(\bar{x}=11.06)$. The result shows that the difference in the mean performance score of the experimental group, Station Rotation Model (SRM) is greater than the difference in mean performance score of the control group, lecture method ( $\overline{\mathrm{D}}: 5.9>0.74)$ in reading comprehension.

\section{Research Question 2}

Do the mean academic performance scores of the male student differ from their female counterparts who were taught reading comprehension using Station Rotation Model (SRM) of Blended Learning Strategy? 
B. A. Ogude \& C. O. Chukweggu; J Adv Educ Philos, Oct 2019; 3(10): 376-383

Table-2: Mean scores of Male and Female students taught using Station Rotation Model (SRM)

\begin{tabular}{|l|l|l|l|l|}
\hline GROUP & GENDER & MEAN PRETEST SCORES & $\begin{array}{l}\text { MEAN POST } \\
\text { TEST }\end{array}$ & MEAN DIFFERENCE $\overline{\mathrm{D}}$ \\
\hline \multirow{3}{*}{ SRM } & Male & 9.64 & 15.08 & 5.44 \\
\cline { 2 - 5 } & Female & 8.92 & 15.44 & 6.52 \\
\hline TOTAL & $\mathbf{N}=\mathbf{5 0}$ & & & \\
\hline
\end{tabular}

\section{Station Rotation Model (SRM)}

Table-2 shows that the mean pretest score of the male students is 9.64 while their mean post-test score is 15.08. Their female counterparts had mean pretest score of 8.92 and a mean post-test score of 15.44, when taught reading comprehension using the Station Rotation Model (SRM) of Blended learning Strategy. The mean difference the mean difference of the female students is greater than those of their male counterparts ( $\bar{D}: 6.52>5.44$ ) hence the female students performed better than the male students in reading comprehension when taught using the Station Rotation Model (SRM).

\section{Test of Hypotheses}

Research Hypotheses $1\left(\mathrm{HO}_{1}\right)$

There is no significant difference between the mean scores of students taught reading comprehension using Station Rotation Model (SRM) form of Blended learning strategy and those taught using Lecture Method (LM).

Table-3: Summary of pretest-post test Analysis of Covariance (ANCOVA) on mean scores of students reading comprehension classified by groups (Station Rotation Model and Lecture Method)

\begin{tabular}{|l|r|r|r|r|r|}
\hline \multicolumn{7}{|c|}{ Tests of Between-Subjects Effects } \\
\hline Dependent Variable: & \multicolumn{1}{l|}{} \\
\hline Source & Type III Sum of Squares & df & Mean Square & F & Sig. \\
\hline Corrected Model & $260.896^{\mathrm{a}}$ & 3 & 86.965 & 6.610 & .000 \\
\hline Intercept & 142.599 & 1 & 142.599 & 10.838 & .001 \\
\hline Group & 3.939 & 1 & 3.939 & .299 & .586 \\
\hline PostTest_SRM_LM & 231.126 & 1 & 231.126 & 17.566 & .000 \\
\hline Group * PostTest_SRM_LM & 33.791 & 1 & 33.791 & 2.568 & .112 \\
\hline Error & 1263.104 & 96 & 13.157 & & \\
\hline Total & 11128.000 & 100 & & & \\
\hline Corrected Total & 1524.000 & 99 & & & \\
\hline a. R Squared =.171 (Adjusted R Squared =.145) \\
\hline
\end{tabular}

Table-3 shows that the F-calculated value is 2.568 while the F-critical value at degree of freedom $\mathrm{df}$ $(1,99)$ is 3.94 . The calculate F-ratio $(2.568)$ is less than the critical value (3.94) at 1 and 99 degree of freedom under 0.05 level of significance. Therefore, the null hypotheses of "no significant difference mean scores of students taught reading comprehension using Station Rotation Model (SRM) form of Blended learning Strategy and those taught using Lecture Method (LM) is upheld. Aptly put, the effect of Station Rotation Model (SRM) on students reading comprehension is statistically insignificant as $\mathrm{F}(1,99)=3.94$.

\section{Research Hypothesis $2\left(\mathrm{HO}_{2}\right)$}

There is no significant difference between mean scores of male and female students taught reading comprehension using station Rotation Model (SRM) of Blended learning strategy.

Table-4: Summary of Analysis of Covariance (ANCOVA) on students' mean scores in reading comprehension taught using Station Rotation Model, classified by gender

\begin{tabular}{|l|r|r|r|r|r|}
\hline \multicolumn{7}{|c|}{ Tests of Between-Subjects Effects } \\
\hline Dependent Variable: & PreTest_SR \\
\hline Source & Type III Sum of Squares & Df & Mean Square & F & Sig. \\
\hline Corrected Model & $73.446^{\text {a }}$ & 3 & 24.482 & 1.226 & .311 \\
\hline Intercept & 79.353 & 1 & 79.353 & 3.974 & .052 \\
\hline Gender & 7.221 & 1 & 7.221 & .362 & .551 \\
\hline PostTest_SR & 66.869 & 1 & 66.869 & 3.348 & .074 \\
\hline Gender* PostTest_SR & 4.056 & 1 & 4.056 & 0.203 & .654 \\
\hline Error & 918.634 & 46 & 19.970 & & \\
\hline Total & 5298.000 & 50 & & & \\
\hline Corrected Total & 992.080 & 49 & & & \\
\hline
\end{tabular}

a. R Squared $=.074$ (Adjusted R Squared $=.014$ ) 
Table-4 shows that the F-calculated value is 0.203 at degree of freedom df $(1,49)$. The F-critical value is 4.03. Since the F-calculated value is less than the F-critical value $(0.203<4.03)$, the null hypothesis is upheld, hence there is no significant difference between mean scores of male and female students taught reading comprehension using Station Rotation Model (SRM) form of the blended learning strategy.

\section{DISCUSSION OF FINDINGS}

The findings of the study that there is a significant difference between means score of students taught reading comprehension using Station Rotation Model (SRM) of the Blended learning Model (BLM) and those taught using lecture Method (LM) are in line with the findings of Chenoweth and Murday [14] in which participants in languages (English, Spanish and French) taught using the Blended Learning Strategy performed better than those in the control group on reading, this finding also agree with Alfiky [7] where blended learning model had a positive effect on the posttest achievement of participants in reading comprehension.

Furthermore, the finding of statistical significance of the Blended Learning Strategy agrees with the findings of Kheirzadeh \& and Birgani [6] that these is a statistically significant difference between the performance of pre-test and post test of experimental group of 30 participants taught using the Blended learning Model at 0.05 significance level and df, 29. The study of Alshmaimeti and Almasri [15] on the effect of web quests on reading comprehension among 30 high school training students using a prêt test and post test control experimental design had a positive significant effect on readers performance, which is in line with the finding of this study. However, the findings of no significant effect of station Rotation Model of the blended Learning strategy on readers mean scores in comprehension agrees with the findings of Munoz and Gonzalez [16] where an experimental pretest post test control design on $38 \mathrm{EFL}$ students of non-equivalent sample (13 men, 25 women) showed no significant difference in achievement levels between experimental and technology based web based Blended learning strategy and the face to face instruction.

The reason for the positive effects of the Interactive Reading Model shown in hypothesis 3, is that it exposes learners to acquisition of knowledge through active participation, and teacher-guided learning. However, the blended learning approach allowed the students, through the digital enhancements, collaborative activities between stations, incorporation of face to face instruction, and child- centeredness in a web-based environment to actively acquire meaningful learning status as shown in the descriptive analysis where students had the mean score difference of 5.9 (Table-3).

\section{CONCLUSION}

The innovative teaching strategy, Station Rotation Model had no significant effect on gender, and students reading comprehension. However, descriptively Station Rotation Model had a greater students mean performance score than the lecture method.

\section{RECOMMENDATIONS}

Based on the findings of this study, the following recommendations were made:

- Teachers should avail themselves with the relevance and potential of Interactive Reading Model to improve students' performance in reading comprehension, hence, making a shift in pedagogy from lecture method to collaborative teaching strategy that is child- centered.

- Teachers should endeavour to apply technology based learning strategies, encourage the use of computer, diverse softwares and computermediated modules for learning. It is meaningful for teachers to obtain adequate training for computer aided instructions (CAI).

- Technology based learning approaches require teacher competence in ICT, this is relevant for guided learning approach, hence teachers should be encouraged through professional development programmes (seminar, workshop, free laptops and in- service training) in order to boost teacher competence and encourage teachers towards the task of effective teaching of reading comprehension in schools.

\section{REFERENCES}

1. Ahmad, A., \& Schreurs, J. (2012). Constructivism based blended learning in higher education. International Journal of Emerging Technologies in Learning (IJET), 20(726)-5.

2. Stevenson, A. (Ed.). (2010). Oxford dictionary of English. Oxford University Press, USA.

3. Gas-coigne, C. (2015). Toward an understanding of the relationship between $\mathrm{L} 2$ reading comprehension and grammatical competence. The reading matrix, 5(2)1-14.

4. Olele, C. N., \& Nwabueze, A. I. (2015). Audio and visual technologies in Digital era: implications for teaching and learning in universities in Rivers State: Nigeria. In Oluwo, S. O., Okoli, N. J., Osaat, S. D., \& Uche, C. M. (eds) years of education in Nigeria: science, ICT and Environmental issues.

5. Tiene, D., \& Ingram, A. (2016). Exploring current issues in Educational technology. Boston: McGraw Hill. (red. Edition) West African Examinations Council: Chief Examiners Report(2011-2016)

6. Kheirzadeh, S., \& Birgani, B. M. (2018). Exploring the Effectiveness of Blended Learning in Improving Reading Comprehension among 
Iranian EFL students. Journal of Applied Linguistics and language research, 1(2)161-170.

7. Alfiky, A. (2011). Blended Learning Educational Design Multimedia, Creative Thinking. Amman (Jordan): Dar Athagafa for publishing and distinguish.

8. Johnson, M. M. (2013). The relationship between spelling ability and reading fluency and comprehension in elementary students USA: University of Nigeria.

9. Ash, K. (2012). Educators evaluate "flipped classroom". Education Week, 32(2):56-58.

10. Yiben, J. J., \& Kitakka, G. (2018). Revolutionary secondary school students reading habits for better academic performance. Nigerian journal of sociology of Education, 12(2)222-226.

11. Anyanwu, E. U., Obichere, C., \& Ossai-Onah, O. V. (2012). The challenges of promoting reading culture in Nigerian children through story hour, book talks and exhibition: A case study of selected secondry schools in Owerri, Imo State. E-journal of Literary Philosophy and Practice, Digital commons@university of Nebraska-Lincolin.
12. Staker, H., \& Horn, M. B. (2012). Classifying K12 blended learning. Innosight Institute.

13. Kim, H. (2013). Effects of use of online forum for problem-solving and collaborative construction of knowledge in student teaching. Paper presented at American Education Research Association in San Francisco, CA.

14. Chenoweth, N. A., \& Murday, K. (2003). Measuring students learning in an online French course. CALICO Journal, 20, 285-314.

15. Alshumaimeri, Y. A., \& Almasri, M. M. (2012). The effects of using WebQuests on reading comprehension performance of Saudi EFL students. Turkish Online Journal of Educational Technology-TOJET, 11(4), 295-306.

16. Ferreira, L., Sánchez-Juanes, F., González-Ávila, M., Cembrero-Fuciños, D., Herrero-Hernández, A., González-Buitrago, J. M., \& Muñoz-Bellido, J. L. (2010). Direct identification of urinary tract pathogens from urine samples by matrix-assisted laser desorption ionization-time of flight mass spectrometry. Journal of clinical microbiology, 48(6), 2110-2115. 